\title{
Cryptic species and species pairs in lichens: A discussion on the relationship between molecular phylogenies and morphological characters
}

\author{
by \\ Ana Crespo \& Sergio Pérez-Ortega \\ Departamento de Biología Vegetal II, Facultad de Farmacia, Universidad Complutense de Madrid, E-28040 Madrid, Spain \\ acrespo@farm.ucm.es, sperezortega@ccma.csic.es
}

\begin{abstract}
Crespo, A. \& Pérez-Ortega, S. 2009. Cryptic species and species pairs in lichens: A discussion on the relationship between molecular phylogenies and morphological characters. Anales Jard. Bot. Madrid 66S1: 71-81.

As with most disciplines in biology, molecular genetics has revolutionized our understanding of lichenized fungi. Nowhere has this been more true than in systematics, especially in the delimitation of species. In many cases, molecular research has verified long-standing hypotheses, but in others, results appear to conflict with existing morphological species concepts. This work reports on recent progress regarding two main issues: (i) cryptic species, i.e., two or more independent lineages exhibiting similar morphology; and (ii) species pairs, two species with similar morphology but exhibiting different reproductive modes. Both concepts have in common a lack of correlation between phylogenetic and morphological data, at least for characters normally used in lichen systematics. We review the available literature on cryptic species and species pairs, focusing especially on the family Parmeliaceae (Lecanoromycetes, Ascomycota). Molecular data have repeatedly demonstrated the existence of cryptic species in lichenized fungi, although taxonomists have often been slow to recognize the resulting taxa. However, careful observation of fine-scale morphological, ecological and/or geographical features tends to provide support for the recognition of these species. In the case of species pairs, by contrast, few if any of the pairs studied to date have been confirmed to consist of independent lineages. Differences in reproductive mode alone appear not to be a sufficient reason to recognise new species.
\end{abstract}

\section{Resumen}

Crespo, A. \& Pérez-Ortega, S. 2009. Especies crípticas y pares de especies en líquenes: una discusión sobre la relación entre la filogenia molecular y los caracteres morfológicos. Anales Jard. Bot. Madrid 6651: 71-81 (en inglés).

Como en otras disciplinas, el impacto producido por la filogenia molecular en el conocimiento de los hongos liquenizados ha producido avances y cambios conceptuales importantes. Esto ha sido especialmente cierto en la sistemática y ha afectado de una manera muy notable en aspectos relacionados con la delimitación de las especies. En muchos casos los datos moleculares han verificado las hipótesis tradicionalmente aceptadas en relación con la definición y el reconocimiento de especies, pero en otros han producido conflictos con el concepto morfológico todavía en uso. Este trabajo trata de los recientes progresos en dos direcciones principales: (i) las especies crípticas, es decir, dos o más linajes independientes que exhiben o aparentan una morfología similar; y (ii) los pares de especies, que son especies con morfología similar pero que exhiben diferentes modos de reproducción. Ambos conceptos tienen en común la falta de correlación entre datos filogenéticos y morfológicos, al menos en lo que se refiere a los caracteres normalmente utilizados en la sistemática de líquenes. Hemos analizado la literatura disponible sobre especies crípticas y pares de especies, centrando los ejemplos preferentemente en la familia Parmeliaceae (Lecanoromycetes, Ascomycota). En los hongos liquenizados, los datos moleculares han demostrado reiteradamente la existencia de especies crípticas, pero los investigadores han sido a menudo muy prudentes a la hora de reconocer como tales los nuevos táxones que se vislumbran. De hecho, las investigaciones se han esforzado en la observación cuidadosa de caracteres morfológicos informativos o de caracteres ecológicos o geográficos; ello está proporcionando un buen apoyo para un sólido planteamiento biológico que va parejo al reconocimiento formal de las especies crípticas. Al contrario, en el caso de los pares de especies, raro es el par de especies, entre los estudiados, en que se haya podido confirmar que realmente se trata de linajes independientes. Por 
Keywords: lichenized Ascomycota, morphological characters, reproductive strategies, species concepts.

\section{Introduction}

The widespread use of molecular phylogenetic markers has led to a breakthrough in the understanding of life and its diversity and a kind of revolution in systematics. Phylogenetic studies provide support for the recognition of natural groups, something to which naturalists have aspired for centuries. In fungi, as in other groups of organisms, a new general classification has been proposed which has a broad consensus (Hibbet \& al., 2007; Lumbsch \& Huhndorf, 2007). At the same time, phylogenetic studies based on the analysis of DNA sequences have been conducted in various families and lineages. However, we still do not completely understand phylogenetic relationships and we do not know how and why phenotypic characters are expressed or altered in many organisms.

There are still many important pieces to discover and place in the puzzle of modern systematics. One of the biggest challenges posed by recent advances in molecular phylogenetics is the disparity between the genetic and morphologic evidences, a situation that often perplexes naturalists. Systematists trained in observing morphological characters expect molecular phylogenies to corroborate or improve their previous hypotheses, but not rarely, molecular phylogenies produce a different picture of relationships between and among the organisms. In the new tree of life, it is not always the case that one organism is replaced by another with 'new' evident characters, as previously thought. The concept of morphological species is increasingly proving insufficient or inadequate for detecting taxa (Mayr, 1942; Taylor \& al., 2000; Hawksworth, 2001; Sáez \& Lozano, 2005; Bickford \& al., 2007). Within the lichenological community, these discordant results have provoked considerable discussion; however, with the notable exception of the recent review by Grube \& Hawksworth (2007) focused on lichen thallus morphology, few attempts have been made to summarize the phylogenetic results in the light of all the evidence.

Current phylogenies have two major shortcomings: the first is that they are based on the analysis of the sequences of a small number of loci, and the second is that the number of sampled major lineages is still limited. It is possible that these two factors are an underlying weakness in many findings. Both problems are tanto parece que las diferencias en el modo de reproducción no son, de por sí, razón suficiente para el reconocimiento de especies distintas.

Palabras clave: caracteres morfológicos, concepto de especie, estrategias reproductivas, hongos liquenizados.

being solved gradually, the first with the arrival of phylogenomics (Delsuc \& al., 2005), and the second with the greater abundance of sequences currently available in GenBank and the improved power and faster speed of algorithms available to analyze the data sets (e.g. Guindon \& Gascuel, 2003; Nixon, 1999). It must also be remembered that the number of characters, usually morphological, that were considered in the past as being useful to identify or classify organisms was also small and they were selected subjectively and did not necessarily reflect the evolutionary patterns.

One of the major problems is that some species, socalled cryptic species that are well defined phylogenetically are not supported by morphological characters and possess no obvious features to separate them (Fig. 1). This situation not only occurs in microscopic fungi but it is also widespread among macromycetes. The concept of cryptic species has been defined and used by many scientists and naturalists for decades with slightly different meanings. The first mention of 'sibling species' in science dates back to the beginning of the twentieth century (Mayr, 1942; 1999). Originally, the term 'sibling species' was applied more narrowly than the concept of 'cryptic species' and implied a 'sister group' phylogenetic relationship. This is the meaning for especies cripticas adopted by Font Quer (1953: 406) and is as established by Mayr (1942) who used it as an example to demonstrate "the vulnerability of the concept of morphological species" (Sáez \& Lozano, 2005). Subsequently, both terms have come to be treated as synonyms in the mycological and most other biological literature. Thus, currently, two or more species are said to be 'cryptic' if they have been traditionally treated as a single taxon because they are apparently morphologically indistinguishable (Bickford \& al., 2007).

The topic has recently been reviewed from a general perspective by Bickford \& al. (2007) and the distribution and number of cryptic species in particular groups has been estimated (Pfenninger \& Schwenk, 2007); so we will restrict our contribution to updating the discussion specific to two issues in lichenized fungi and their taxonomic consequences, using mainly examples from the Parmeliaceae (Lecanoromycetes), a widespread and well known family of macrolichens: (i) the presence of cryptic species; and (ii) the phylo- 
genetic status of so-called 'species pairs'. Both concepts have in common a lack of correlation between phylogenetic and morphological data, at least for characters normally used in lichen systematics. For the cryptic species, we will emphasize their common occurrence in several groups and also present some recommendations on their recognition. For 'species pairs' we will summarise recent results on the topic. For a matter of practical definition, we use 'lichen' here as synonymous with the fungal partner, the mycobiont.

\section{Phylogeny and characters in lichen-forming fungi}

In fungi, the inconsistencies between phylogenetic representations based on molecular data and those based on morphological and chemical characters are common and affect both infrageneric and suprageneric taxa (Taylor \& al., 2000; Grube \& al., 2004; Bickfold \& al., 2007). A possible explanation may be that fungi, unlike other pluricellular organisms such as vertebrates or vascular plants, have a relatively limited suite of morphological characters of taxonomic use. In addition there is a deficiency of comparative studies of ontogeny in tissues or organs and, due to the small size of the fungal chromosomes, there are no karyological data, often used as helpful characters in the taxonomy of vascular plants.

Other reasons that explain the ambiguity or discrepancy between the phylogenetic and morphological data in the systematics of fungi include the existence of a large number of unicellular yeast-like fungi, as well as a high number of species whose life cycle is unknown or from which only the anamorphic state is known. The number of available characters among the anamorphs is even lower than in the sexual state and it has been shown that a high level of convergence exists between different lineages (e.g. Campbell \& al., 2006; Crous \& al., 2006). Furthermore, the absence of an extensive fossil record in fungi makes it difficult to understand the historical development of the characters themselves, and to date their acquisition or loss in evolutionary time (Taylor \& al., 2004). Lichens, are no the exception to this pattern; to the contrary, the pre-sence of convergent morphologies between phylogenetically distant groups is frequent (Blanco \& al., 2004a, b; Grube \& al., 2004; Molina \& al., 2004; Schmitt \& al., 2005; Grube \& Hawksworth, 2007).

It is well-known among naturalists and lichenologists that it is difficult to identify lichens in the field, even when one is dealing with a macrolichen, and non-experts can mistake not only species, but even the genus or the family. For the molecular systematist, the symbiotic nature of lichens -in which nomenclature and systematics are based on the fungal symbiont- causes difficulties in the lab as specific fungal primers are needed in order to avoid cross-contaminations (including with the photobiont) at amplification steps in polymerase chain reaction (PCR).

From the first studies using molecular techniques in the nineties it was confirmed that lichenization is not a specific feature of any particular group of fungi but it is rather a 'life style' that has appeared in different groups of fungi at different evolutionary times (Gargas \& al., 1995). Furthermore, it has been shown that capacity to live together with an alga has been in-

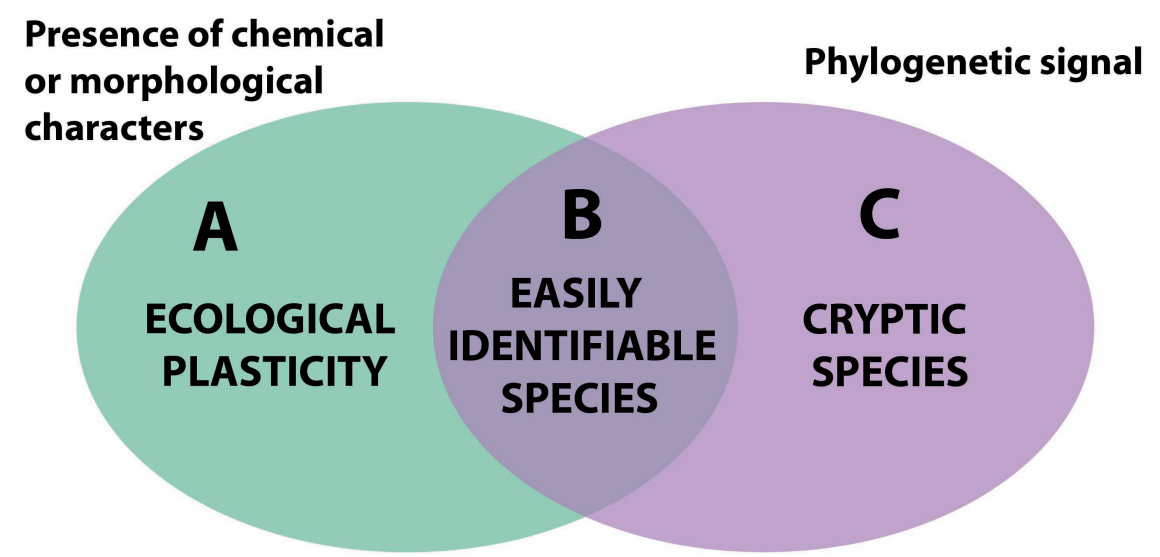

Fig. 1. A, The presence of distinctive differences in morphological or chemical characters among different populations in lichens is not always correlated to the existence of different taxa. B, The combination of the existence of morphological and/or chemical characters with the presence of phylogenetic signal makes the acceptance of taxa. $\mathbf{C}$, On the other hand, the presence of phylogenetic signal, usually together with other features such as biogeographical or ecological patterns, but in the absence of other easily recognizable characters, lead to the presence of the so-called cryptic species. 
dependently gained and lost several times within the fungal tree of life (Lutzoni \& al., 2001).

The acquisition and loss of morphological and chemical characters in lichens has been studied both in large monophyletic groups at the rank of family (e.g. Wedin, 1993; Ihlen \& Ekman, 2002; Reeb \& al., 2004; Lumbsch \& al., 2006; Gueidan \& al., 2007; Crespo \& al., 2007; Lumbsch \& al., 2007; Ekman \& al., 2008) and in smaller groups (e.g. Blanco \& al., 2006; Buschbom \& Baker, 2006; Tehler \& Irestedt, 2007; Otálora \& al., 2008; Ertz \& al., 2009). With some rare exceptions, most of the characters analyzed turned out to be homoplaseous, and have been gained or lost several times in different lineages. However many characters that are homoplaseous at the family level can behave as differential or synapomorphic in lower taxa such as genera and species. Related species and related genera may share morphological and/or chemical characters inherited from a common ancestor but these same characters can be also found in unrelated groups where they have appeared independently. Molecular phylogenetic data have led to the revision of morphological and chemical characters and their taxonomical significance in different groups (e.g. Högnabba \& Wedin, 2003; Schmitt \& al., 2005; Divakar \& al., 2005a; Lumbsch \& al., 2006; Argüello \& al., 2007; Gueidan \& al., 2007; Kalb \& al., 2008) whilst the search for characters to support the phylogenetic topologies has yielded new and useful morphological features that were previously unnoticed (e.g. del Prado $\&$ al., 2007). However it must be stressed that, in many cases, independent, clearly monophyletic taxa do not possess apparently morphological characters that allow an unequivocal morphological identification. In such cases, and when different geographical distributions are recognizable, several authors have proceeded to propose new species or genera using biogeography as a supporting character (Argüello \& al., 2007; Divakar \& al., in press). Similarly, different ecological behaviour has also been used to validate the recognition of cryptic taxa, e.g. the occurrence of Parmelia serrana on bark versus $P$. saxatilis commonly on rock (Molina $\&$ al., 2004).

\section{Cryptic species}

Many studies investigating intraspecific genetic variability in fungi have detected cryptic species (Taylor \& al., 2000; Rokas \& al., 2007). Their occurrence was first recognized in pathogenesis and intercompatibility studies (Geiser \& al., 1998; Aanen \& Kuyper, 1999). This phenomenon also occurs in lichens and has been reported in several groups (De los Ángeles \& al., 2001; Kroken \& Taylor, 2001; Crespo \& al., 2002).
However, although cryptic species have been found among lichens, taxonomic decisions have frequently not been made and, in some cases, authors have temporarily refrained from naming taxa due to incomplete sampling (Wirtz \& al., 2008) or because of weak support from an analysis based on a single locus (Crespo \& al., 2002).

The first references to the existence of cryptic lineages in lichens and lichen-related fungi date to the early part of this decade when, in 2001, two different studies showed the presence of hidden phylogenetic species within widespread and well known lichens. Kroken \& Taylor (2001), in a multilocus study of the morphospecies pair Letharia vulpina-L. columbiana, detected the presence of at least six different phylogenetic species, some of which had subtle morphological differences that had been previously overlooked. Likewise, de los Angeles \& al. (2001) showed the presence of cryptic species within the widespread pin lichen-related fungi Mycocalicium subtile, based on a single locus.

Characters such as vegetative reproductive structures, secondary metabolites and cilia, have been used in the Parmeliaceae to delineate many species. However, these features can be present in lineages that are not necessarily closely related and they may have been gained and lost several times (Blanco \& al., 2006; Crespo \& al., 2007). It seems that these characters are easily acquired independently in situations where they may convey competitive advantage. Records of vegetative structures in species in which they are usually absent, suggests that even species that rarely form these structures possess the genes required for their expression (Kärnefelt, 1979; Ferencová \& al., in rev.).

In addition, phylogenetically unrelated but morphologically similar lineages can often occur sympatrically. This is the case for several broadly defined morphospecies within the Parmeliaceae (e.g. Parmelia saxatilis, P. sulcata and Parmelina quercina) which contain different separate phylogenetic clades with identical morphology, and exist side by side in some areas of their distribution range, such as the British Isles, the Iberian Peninsula or the mountains of northern Morocco (Crespo \& al., 2002; Argüello \& al., 2007).

One of the more reliable ways to show whether two organisms or populations belong to different but cryptic species, would be to carry out experimental crosses under controlled conditions to confirm whether a reproductive barrier exists between them. In lichens these experiments are not yet feasible. However, the analysis of intraspecific genetic variability among populations of different species has produced convincing clues to suggest that cryptic isolated lineages occur within morphospecies in many dif- 
ferent groups of Parmeliaceae. For example, several cases have been detected in the Parmeliaceae, where the presence of cryptic species is not restricted to any particular mode of reproduction. Cryptic lineages have been reported in apotheciate taxa such as Parmelina quercina (Argüello \& al., 2007), the isidiate Parmelia saxatilis (Crespo \& al., 2002; Molina \& al., 2004) and the sorediate Parmotrema reticulatum (Divakar \& al., 2005b). It should be noted that, although available studies are unequivocal in revealing cryptic lineages within lichen morphospecies, the lack of molecular markers with greater resolution tends to limit studies in some groups of lichens. In addition to these problems, population studies suggest that genetic drift between isolated lichen populations is slow (Printzen \& al., 2003), which could lead to paraphyly in many lineages.

Lichens often have larger geographical ranges than vascular plants, with many species showing continental disjunctions in their distribution ranges (Galloway, 2008). Cosmopolitan species, i.e., those with a worldwide distribution, are better candidates for possessing high genetic variability (Murtagh \& al., 2002; Myllis \& al., 2003). Two are the most striking distribution models found in lichens; one is the so-called bipolar model (Galloway \& Aptroot, 1995; Galloway, 2008) where species are distributed in polar regions in both hemispheres (and frequently also on high mountains at lower latitudes) and the other is the biogeographic Mediterranean pattern in which several species are distributed through the different regions with a Mediterranean climate (Barreno, 1991; Galloway \& Aptroot, 1995).

Parmelia saxatilis, a common species in Europe with an almost continuous cosmopolitan distribution, has been investigated using ITS and $\beta$-tubulin nuclear DNA sequences (Crespo \& al., 2002; Molina \& al., 2004; Feuerer \& Thell, 2002; Thell \& al., 2007). The reconstruction of phylogenetic relationships among samples from regions as far apart as Antarctica, Arctic Europe and North America revealed the presence of several monophyletic, occasionally sympatric, independent lineages. Some of them also exhibited slight, almost cryptic, morphological, chemical and ecological differences that supported the recognition of two new species (P. ernstiae and P. serrana) (Thell \& al., 2008).

The detailed study of genetic variability in different infraspecific lineages of $P$. saxatilis has provided information about its evolutionary history. The species as traditionally circumscribed includes several cryptic lineages, of which some are sympatric and others allopatric, growing on opposite sides of the Atlantic
Ocean (Molina \& al., 2004; Molina \& al., in prep.). One of the lineages has a bipolar distribution with saxicolous forms whose range extends from pole to pole, but, interestingly, with minimal genetic variability (Crespo \& al., 2002). Other lineages in the study had much more limited distributions in America or in Europe and North Africa; one of them, described from Europe as $P$. serrana, has a higher genetic diversity than $P$. saxatilis, but with a smaller distribution range (Del Prado \& al., in rev.).

Parmelina quercina is another member of the Parmeliaceae showing sexual mode of reproduction and having disjunct distribution pattern. The species was known as a single taxon, occurring in most regions of the world with humid Mediterranean climate, including North America, Australia and Europe. An analysis of genetic variability of $P$. quercina with several markers (Argüello \& al., 2007) that included samples from all the major regions where the species was reported, found several different independent lineages within the species. Specimens from Europe and North Africa were grouped in two independent monophyletic lineages that overlapped geographically. Specimens from California (USA) grouped in a third lineage whilst Australian specimen formed a sister group to the other three lineages with a large genetic difference from all other samples. The comparative study of morphological characters of the different lineages led to the detection of subtle distinguishing characters in each one. The two lineages with European and North African specimens fit well into the concept of morphological species P. quercina and P. carporrbizans, both of which had been recognized before. The remaining two lineages were described as new species, $P$. coleae (USA) and P. elixia (Australia).

Although relationships between the two European and American clades are not fully supported, it seems that the time of separation between these lineages has been longer than between the European and North African groups. However, the morphological characters are subtle, and only slight differences in ascospore shape and size allow the separation of $P$. coleae, the Californian lineage, from $P$. quercina s. str. P. quercina and $P$. coleae are a good example of cryptic species where the absence of obvious taxonomic characters has obscured the taxonomy, although the geographical distribution allows naming of the two cryptic species. The two European species, P. quercina and P. carporrbizans, are by contrast easily distinguishable morphologically after the re-evaluation of the characters.

The Australian samples showed a large genetic distance from the rest of the lineages of $P$. quercina s. lat. and also possessed ascospores notably different in size 
and shape. In a subsequent multilocus study of the entire genus Parmelina from Australia, it has been observed that they belong to another clade entirely separate from the taxa of the Northern Hemisphere. This result was unexpected considering the apparent morphological similarity between Parmelina quercinas. str. and P. 'quercina' from Australia (inedited name Austroparmelina elixia) but also between the whole genus Parmelina from the Northern Hemisphere and the 'false' genus Parmelina (inedited Austroparmelina) from Australia (Divakar \& al., 2008). A similar phylogeographic pattern to that observed in P. querci$n a$ has been discovered in Melanelixia glabra, another parmelioid macrolichen that has comparable ecology and distribution (Divakar \& al., in press). American populations from California of this morphospecies were found to represent a cryptic species (M. californica) phylogenetically clearly delimited.

In these two cases (P. quercina s. lat. and M. glabra s. lat), the new species recognized as a result of genetic work can be distinguished by subtle morphological and/or geographic traits, but the Bickford \& al.(2007) definition of cryptic species is nonetheless applicable. In both cases the recognized new species had been previously classified as a single broadly interpreted species because they were at least superficially morphologically indistinguishable. The breakdown of the traditional taxonomic concepts of $P$. quercina, $M$. glabra and some other species from different groups suggests that the notion of widespread and/or widely disjunct taxa should be critically reviewed in other lichen taxa as well.

\section{Recognition of cryptic species lineages}

Species concept and species delimitation have been recently reviewed in a broad sense by de Queiroz (2007) and in lichens by Grube \& Kroken (2000), these topics, therefore, shall not be revisited in the present work. The presence of lineages of cryptic species poses a major problem that affects not only taxonomy, but also other fields of biology such as biodiversity research and conservation policy (Bickford \& al., 2007). Nonetheless, the problem is not a new one. In many ways it is comparable to the release of the microscope in the 17th century; the more accurate the instruments that the researchers are using, the more precise the information about the studied organisms that is available to detect differences. The present use of molecular characters has advanced taxonomy dramatically and the identification and recognition of species of bacteria, protists or yeast is now a possibility that was not anticipated only a few decades ago (Hawksworth, 2001).

No scientist working on systematics doubts the use- fulness of having a 'name' and a formal 'diagnosis' for all the cryptic species, and their discovery has been welcomed in fields such as clinical mycology. However, the emergence of cryptic species in other fungal groups such as macromycetes and macrolichens has ignited a passionate debate.

Faced with these controversies, we can go back to when the microscope was introduced in lichenology. How many new species have been described with its use? Or, put another way, how many species of lichens can be identified today without checking their ascospores, their excipulum structure or the shape of their paraphyses? Likewise, how many species in some major groups of macrolichens of Parmeliaceae or Cladoniaceae could be identified without the help of the thin layer chromatography? The answer is that some species can be recognized because they possess an easily detectable character while many others need special facilities to be identified.

It must be accepted that the recognition of lichen species frequently requires access to adequate instruments to observe the differences between species. The identification of cryptic lineages, based on characters provided by molecular biology, is only a step towards the best resolution of scientific challenges in the study and recognition of biodiversity.

The implications of the presence of cryptic species to the taxonomic recognition of new species were treated in detail by Taylor \& al. (2000). The authors pointed out the inadequacy of the morphological concept of species for practical uses, e.g., in medicine and industry and for conservation purposes (Bickford \& al., 2007).

The large and increasing number of cryptic lineages detected in fungi means that the recognition of these species as separate taxa is not merely a local problem. Hawksworth (2001), when critically analyzing his estimate of 1.5 million species of fungi on earth (Hawksworth, 1991) found several reasons to consider this number to be very low. In fact, Hawksworth (2001) states that 'allowances for cryptic species, now known to be widespread by incompatibility and molecular studies, could on their own justify an upward revision (of 1.5M species) by a factor of at least five'. Notwithstanding this assertion, he recommended the use of 'morphological species' as a practical solution, despite the fact that it could be para- or polyphyletic, or admitting that in one 'morphological species' more than one reproductively isolated lineage may be included, as had been previously suggested by other authors (Petersen \& Hughes, 1998).

This 'pragmatic' proposal (Hawksworth, 2001: 1429 ) is now probably insufficient following the latest 
evidence, especially considering the increasing number of cryptic lineages found in the population studies of many of the major fungal groups in the recent literature. Furthermore, this pragmatic view of the concept of species can be problematic in the field of conservation biology where it is crucial to identify conservation units that correspond to monophyletic species in order to generate specific policies and plans for the individual conservation requirements of each taxon (Purvis \& al., 2005; Bickford \& al., 2007).

Distinguishing between structured populations within a species and different species using molecular data is an extremely complex issue that has provoked heated debate and is far from being resolved. The recognition of cryptic species as a taxonomic entity should be based on a reasonable balance between some essential preconditions and other optional criteria. The basic conditions are:

- molecular markers used should possess sufficient levels of variability to detect differences at the range of species or lower.

- analysis should be based on more than one independent genetic region, in order to detect recombination events among lineages.

- it is necessary to support the decision by contrasting the results using suitable statistical tools.

Using the topology of the phylogenetic reconstruction (tree or network), the optional criteria that should be considered are:

- to review the maximum possible number of morphological and chemical characters; clustering the samples according to their phylogenetic relationship can be of great help in the reinterpretation of existing characters or to deduce or discover new characters.

- to verify whether the affected populations have a unique ecology in comparison with other related lineages.

- to verify whether the affected populations have a particular geographical distribution in comparison with other related lineages.

Although monophyly is to be expected for independent lineages or species, several phenomena, such as hybridization, introgression and incomplete lineage sorting, operating at the population level, may provide scenarios where haplotypes are not reciprocally monophyletic. This topic has been treated in numerous papers (see for example Wiens \& Penkrot, 2002; Knowles \& Carstens, 2007; Maddison \& Knowles, 2006) and even new species concepts have been proposed to handle this situation (e.g. Templeton, 1989).

\section{Species pairs}

It is also possible to find the reverse of the cryptic species situation, the case where morphologically clearly delimited species are not supported by molecular data. There is evidence of this lack of correspondence of morphological characters and the phylogenetic reconstructions in groups as diverse as Lecanora (Pérez-Ortega \& Printzen, 2008) and Xanthoparmelia, in which certain chemical syndromes are not reflected in molecular differences (Amo \& al., in prep.). Likewise, the case of photosymbiodemes, two different primary photobionts associated with a single fungal species producing different thallus morphology, is paradigmatic and from the earliest days of molecular research in lichens it has been shown that they are formed by the same fungal species (Armaleo \& Clerc, 1991).

Differences in the reproductive mode of otherwise morphologically similar species have been an object of special interest in the lichenological literature. The so-called 'species pairs' are taxa suspected to be phylogenetically closely related but which differ in their reproductive structures. One species, often called the 'primary' species, has sexual reproductive structures, while its counterpart, termed the 'secondary' species, reproduces by means of vegetative structures. The increasing abundance of references in the literature to these pairs of species suggests that it is a worthwhile subject to be discussed in the light of recent phylogenetic data.

The concept of 'species pairs' dates from Du Rietz (1924) and was later extended, discussed and reviewed by various authors (Poelt, 1963, 1970, 1972; Hale, 1965; Bowler \& Rundel, 1975; Robinson, 1975; Tehler, 1982). The history of the use of this concept in lichenology has been reviewed in depth by Mattsson \& Lumbsch (1989). Several theories have been proposed to explain the presence of these pairs. Poelt (1963) suggested the presence of one primary sexual taxon which, following a one-time event, produced a new lineage that reproduced asexually, the secondary taxon. Later, Tehler (1982) suggested the occurrence of multiple change events ("spin-offs"), of vegetative lineages from the sexually active lineage; the changes occurred several times and could be short-lived, as he considered asexual counterparts as dead-ends. Robinson (1975), by contrast, proposed that the two putative taxa, fertile and vegetative, belong to a single lineage in which panmixia and recombination occurs.

More recently, Buschbom \& Mueller (2006) proposed a new theory in which the founding species of the pair could be a species with either vegetative or sexual reproduction. These autors suggested that changes 
in the reproductive mode are governed by trade-offs in the fitness of the symbiosis. Thus, when the relationship between mycobiont and photobiont is optimal in a given environment, the preponderant reproductive mode is asexual. When changes in the environment make the established symbiosis suboptimal, however, producing a reduction in the global fitness, sexual reproduction will be preferred in order to 'escape' from the photobiont, opening up access to new partners and producing variability through recombination.

Although their hypothesis is biologically plausible and offers an explanation for all described species pairs, these authors based their theory on two assumptions: (i) that asexual populations of fungal species are not viable in the long term owing to the presumed inability of the clone to adapt to environmental change, and (ii) that the lichen consortium remains constant through asexual reproduction, i.e., biont switching does not take place. However, it has recently been shown that asexual lineages in Lecanoromycetes are not only able to generate genetic diversity but also to have multiple speciation events (Ekman \& Tønsberg, 2002; Ferher \& al., 2008). Furthermore, it has been also shown that even in the absence of sexual reproduction, lichens are able to exchange photobionts (algal switching; Piercey-Normore, 2006; Nelsen \& Gargas, 2008; Yahr \& al., 2006). We think that there are still many open questions in relation to how the dynamics of reproductive modes evolve in populations. More thorough studies, such as the one on the species pair Porpidia flavocoerulescens-P. melinodes by Buschbom \& Mueller (2006) are needed if we are to better understand the biological processes underlying the formation and stability of species pairs, and the role of the photobiont in those processes.

What has been revealed in most of the numerous examples of species pairs studied so far, belonging to the families Physciaceae (Lohtander \& al., 2000; Myllys \& al., 2001; Cubero \& al., 2004), Roccellaceae (Lohtander \& al., 1998a,b; Myllys \& al., 1999), Lecideaceae (Buschbom \& Mueller, 2006) and Parmeliaceae (Artikus \& al., 2002), is that the molecular evidence suggests that both members of the putative species pairs form a single monophyletic group. Robinson (1975), who anticipated the monophyly of sexual-asexual species pairs, went further, proposing that the broadly defined, inclusive species would consist of a single, panmictic population. Molecular evidence does not, however, support the latter hypothesis: multiple independent lineages are present, though not corresponding to reproductive mode and not highly supported.
Not all sexual-asexual species pairs that have been tested, however, have proved to consist of a single, all-inclusive monophyletic lineage. In a study of Letharia columbiana and L. vulpina, Kroken \& Taylor (2001) showed that a putative sexual-asexual species pair could in fact be broken down into no fewer than six cryptic taxa.

Finally, it has to be said that the equating of isidia with soredia has led to an assumption that parallel 'species pairs' also exist, with the isidiate species acting as secondary species of morphologically and chemically identical, fertile counterparts. Preliminary molecular data from our lab have shown that the situation with isidiate species is probably much more complex than species pairs involving sorediate taxa.

\section{Acknowledgements}

The authors would like to thank T.G. Allan Green (Universidad Complutense de Madrid, Spain) and Toby Spribille (University of Graz, Austria) for the linguistic revision of the manuscript, to David L. Hawksworth (Universidad Complutense de Madrid), Toby Spribille, Óscar Blanco (Instituto Nacional de Consumo, Madrid) and Paloma Cubas (Universidad Complutense de Madrid) for critical comments and suggestions and two anonymous referees for helpful observations. This work was supported by the Spanish Ministerio de Ciencia e Innovación (CGL 200764652/BOS, CGL2008-01125-E/BOS). SPO was supported by the project ANT-COMPLEX (CGL2006-12179-CO2-01, MEC, Spain).

\section{References}

Aaren, D.K. \& Kuyper, T.W. 1999. Intercompatibility tests in the Hebeloma crustuliniforme complex in northwestern Europe. Mycologia 91: 783-795.

Argüello, A., del Prado, R., Cubas, P. \& Crespo, A. 2007. Parmelia quercina (Parmeliaceae, Lecanorales) includes four phylogenetically supported morphospecies. Biological Journal of the Linnean Society 91: 455-467.

Armaleo, D. \& Clerc, P. 1991. Lichen chimeras: DNA analysis suggests that one fungus forms two morphotypes. Experimental Mycology 15: 1-10.

Articus, K., Mattsson, J-E., Tibell, L., Grube, M. \& Wedin, M. 2002. Ribosomal DNA and $\beta$-tubulin data do not support the separation of the lichens Usnea florida and U. subfloridana as distinct species. Mycological Research 106: 412-418.

Barreno, E. 1991. Phytogeography of terricolous lichens in the Iberian Peninsula and the Canary Islands. Botanika Chronika 10: 199-210.

Bickford, D., Lohman D.J., Sodhi, N. S, Ng, P.K.L., Meier, R., Winker, K., Ingram, K.K. \& Das, I. 2007. Cryptic species as a window on diversity and conservation. Trends in Ecology and Evolution 22: 148-155.

Blanco, O., Crespo, A., Divakar, P.K., Esslinger, T.L., Hawksworth, D.L. \& Lumbsch, H.T. 2004a. Melanelixia and Melanohalea, two new genera segregated from Melanelia (Parmeliaceae) based on molecular and morphological data. Mycological Research 108: 873-884. 
Blanco, O., Crespo, A., Elix, J.A., Hawksworth, D.L., \& Lumbsch, H.T. 2004b. A molecular phylogeny and a new classification of parmelioid lichens containing Xanthoparmelia-type lichenan (Ascomycota: Lecanorales). Taxon 53: 959-975.

Blanco, O., Crespo, A., Ree, R.H. \& Lumbsch, H.T. 2006. Major clades of parmelioid lichens (Parmeliaceae, Ascomycota) and the evolution of their morphological and chemical diversity. Molecular Phylogenetics and Evolution 39: 52-69.

Bowler, P.A. \& Rundel, P.W. 1975. Reproductive strategies in lichens. Botanical Journal of the Linnean Society 70: 325-340.

Buschbom, J. \& Barker, D. 2006. Evolutionary history of vegetative reproduction in Porpidia s.l. (lichen-forming Ascomycota). Systematic Biology 55: 471-484.

Buschbom, J. \& Mueller, G.M. 2006. Testing “species pair” hypotheses: evolutionary processes in the lichen-forming species complex Porpidia flavocoerulescens and Porpidia melinodes. Molecular Biology and Evolution 23: 574-586.

Campbell, J., Shearer, C. \& Marvanová, L. 2006. Evolutionary relationships among aquatic anamorphs and teleomorphs: Lemonniera, Margaritispora, and Goniopila. Mycological Research 110: 1025-1033.

Crespo, A., Molina, M.C., Blanco, O., Schroeter, B., Sancho, L.G. $\&$ Hawksworth, D.L. 2002. rDNA ITS and $\beta$-tubulin gene sequence analyses reveal two monophyletic groups within the cosmopolitan lichen Parmelia saxatilis. Mycological Research 106: 788-795.

Crespo, A., Lumbsch, H.T., Mattsson, J.-E., Blanco, O., Divakar, P. K., Articus, K., Wiklund, E., Bawingan, P.A., Wedin, M. 2007. Testing morphology-based hypotheses of phylogenetic relationships in Parmeliaceae (Ascomycota) using three ribosomal markers and the nuclear RPB1 gene. Molecular Phylogenetics and Evolution 44: 812-824.

Crous, P.W., Wingfield, M.J., Mansilla, J.P., Alfenas, A.C. \& Groenewald, J.Z. 2006. Phylogenetic reassessment of Mycosphaerella spp. and their anamorphs occurring on Eucalyptus. II. Studies in Mycology 55: 99-131.

Cubero, O.F., Crespo, A., Esslinger T.L. \& Lumbsch, H.T. 2004. Molecular phylogeny of the genus Physconia (Ascomycota, Lecanorales) inferred from a Bayesian analysis of nuclear ITS rDNA sequences. Mycological Research 108: 498-505.

De los Ángeles Vinuesa, M., Sanches-Puelles, J.M. \& Tibell, L. 2001. Intraspecific variation in Mycocalicium subtile (Mycocaliciaceae) elucidated by morphology and the sequences of the ITS1-5.8S-ITS2 region of rDNA. Mycological Research 105: 323-330.

De Queiroz, K. 2007. Species concepts and species delimitation. Systematic Biology, 56: 879-886

Delsuc, F., Brinkmann, H. \& Philippe, H. 2005. Phylogenomics and the reconstruction of the tree of life. Nature Review Genetics 6: 361-75.

Del Prado, R., Ferencovà, Z., Armas-Crespo, V, Amo de Paz, G., Cubas, P. \& Crespo, A. 2007. The arachiform vacuolar body, an overlooked shared character in the ascospores of a large monophyletic group within Parmeliaceae (Xanthoparmelia clade, Lecanorales). Mycological Research 111: 685-693.

Divakar, P.K., Molina, M.C., Lumbsch, H.T. \& Crespo, A. 2005a. Parmelia barrenoae, a new lichen species related to Parmelia sulcata (Parmeliaceae) based on molecular and morphological data. Lichenologist 37: 37-46.

Divakar, P.K., Blanco, O, Hawksworth D. L. \& Crespo A. 2005b. Molecular phylogenetic studies on the Parmotrema reticulatum (syn Rimelia reticulata) complex, including the confirmation of P. pseudoreticulatum as a distint species. Lichenologist 37:55-65.
Divakar, P.K., Crespo, A., Kauff, F., del Prado, R., Pérez-Ortega, S., Amo de Paz, G., Ferencová, Z., Blanco, O., Argüello, A., Millanes, A., Molina, M.C., Piercey-Normore, M.P., Wedin, M., Aptroot, A., Bungartz, F., Calvelo, S., Candan, M., Cole, M., Elix, J.A., Ertz, D., Goffinet, B., Knight, A., Lendemer, J., Lindblom, L. Lücking, R., Lutzoni, F., Mattsson, J-E., Messuti, M.I., Perlmutter, G., Rico, V.J., Spribille, T., Steffen, U.P., Sweat, K., Thell, A., Thor, G., Urbanavichus, G. \& Lumbsch, T.H. 2008. New systematics and generic circumscription of parmelioid lichens inferred from multigene analysis. Abstracts of the IAL 6, Asilomar, California.

Divakar, P.K., Figueras, G., Hladun, N. \& Crespo, A. 2009. Morphological versus phylogenetic species: An example from Melanelixia glabra (Parmeliaceae, Ascomycota). Fungal Diversity (in press)

Du Rietz, G.E. 1924. Die Soredien und Isidien der Flechten. Svensk Botanisk Tidskrift 18: 371-396.

Ekman, S. \& Tønsberg, T. 2002. Most species of Lepraria and Leproloma form a monophyletic group closely related to Stereocaulon. Mycological Research 106: 1262-1276.

Ekman, S., Andersen, H.L. \& Wedin, M. 2008. The limitations of ancestral state reconstruction and the evolution of the ascus in the Lecanorales (Lichenized Ascomycota). Systematic Biology 57: $141-156$

Ertz, D., Miadlikowska, J., Lutzoni, F., Dessein, S., Raspé, O., Vigneron, N., Hofstetter, V. \& Diederich, P. 2009. Towards a new classification of the Arthoniales based on a three-gene phylogeny focusing on the genus Opegrapha. Mycological Research 113: 141-152.

Fehrer, J., Slavíková-Bayerová, Š. \& Orange, A. 2008. Large genetic divergence of new, morphologically similar species of sterile lichens from Europe (Lepraria, Stereocaulaceae, Ascomycota): concordance of DNA sequence data with secondary metabolites. Cladistics 24: 443-458.

Feuerer, T. \& Thell, A. 2002. Parmelia ernstiae - a new macrolichen from Germany. Mitteilungen aus dem Institut für Allgemeine Botanik in Hamburg 30-32: 49-60.

Font Quer, P. 1953. Diccionario de Botánica. Editorial Labor, S.A. Galloway, D.J. 2008. Lichen biogeography. In: Nash, T.H. III. Lichen Biology. Cambridge University Press, Cambridge.

Galloway, D.J. \& Aptroot, A. 1995. Bipolar lichens: a review. Cryptogamic Botany 5: 184-191.

Gargas, A., DePriest, P.T., Grube, M. \& Tehler, A. 1995. Multiple origins of lichen symbioses in fungi suggested by SSU rDNA phylogeny. Science 268: 1492-1495.

Geiser, D.M., Pitt, J.I. \& Taylor, J.W. 1998. Cryptic speciation and recombination in the aflatoxin-producing fungus Aspergillus flavus. Proceedings of the National Academy of Sciences of the United States of America 95: 388-393.

Grube, M. \& Kroken, S. 2000. Molecular approaches and the concept of species and species complexes in lichenized fungi. $M y$ cological Research 104: 1284-1294.

Grube, M., Baloch, E. \& Lumbsch, H.T. 2004. The phylogeny of Porinaceae (Ostropomycetidae) suggests a neotenic origin of perithecia in Lecanoromycetes. Mycological Research 108: 11111118.

Grube, M. \& Hawksworth, D.L. 2007. Trouble with lichen: the reevaluation and re-interpretation of thallus form and fruit body types in the molecular era. Mycological Research 111: 1116-1132.

Gueidan, C., Roux, C. \& Lutzoni, F. 2007. Using a multigene phylogenetic analysis to assess generic delineation and character evolution in Verrucariaceae (Eurotiomycetes, Ascomycota). Mycological Research 111: 1145-1168. 
Guindon, S. \& Gascuel, O. 2003. A simple, fast, and accurate algorithm to estimate large phylogenies by maximum likelihood. Systematic Biology 52: 696-704.

Hale, M.E. Jr. 1965. A monograph of Parmelia subgenus Amphigymnia. Contributions from the United States National Herbarium .36: 193-358.

Hawksworth, D.L. 1991: The fungal dimension of biodiversity: magnitude, significance, and conservation. Mycological Research 95(6): 641-655.

Hawksworth, D.L. 2001. The magnitude of fungal diversity: the 1.5 million species estimate revisited. Mycological Research 105 $1422-1432$

Hibbett, D.S., Binder, M., Bischoff, J.F., Blackwell, M., Cannon, P.F., Eriksson, O., Huhndorf, S., James, T., Kirk, P.M., Lücking, R., Lumbsch, H.T., Lutzoni, F., Matheny, P.B., McLaughlin, D.J., Powell, M.J., Redhead, S., Schoch, C.L., Spatafora, J.W., Stalpers, J.A., Vilgalys, R., Aime, M.C., Aptroot, A., Bauer, R., Begerow, D., Benny, G.L., Castlebury, L.A., Crous, P.W., Dai, Y.- C., Gams, W., Geiser, D.M., Griffith, G.W., Gueidan, C., Hawksworth, D.L., Hestmark, G., Hosaka, K., Humber, R.A., Hyde, K., Koljalg, U., Kurtzman, C.P., Larsson, K.-H., Lichtward, R., Longcore, J., Miadlikowska, J., Miller, A., Monclavo, J.-M., Mozley- Standridge, S., Oberwinkler, F., Parmasto, E., Reeb, V., Rogers, J.D., Roux, C., Ryvarden, L., Sampaio, J. P., Schuessler, A., Sugiyama, J., Thorn, R. G., Tibell, L., Untereiner, W. A., Walker, C., Wang, Z., Weir, A., Weiss, M., White, M., Winka, K., Yao, Y.-J., Zhang, N. 2007. A higherlevel phylogenetic classification of the Fungi. Mycological Re search 111: 509-547.

Högnabba, F. \& Wedin, M. 2003. Molecular phylogeny of the Sphaerophorus globosus species complex. Cladistics 19: 224232.

Ihlen, P.G. \& Ekman, S. 2002. Outline of phylogeny and character evolution in Rhizocarpon (Rhizocarpaceae, lichenized Ascomycota) based on nuclear ITS and mitochondrial SSU ribosomal DNA sequences. Biological Journal of the Linnean Society 77: 535-546.

Kärnefelt, I. 1979. The brown fruticose species of Cetraria. Opera Botanica 46: 1-150.

Kalb, K., Staiger, B., Elix, J.A., Lange, U. \& Lumbsch, H.T. 2008. A new circumscription of the genus Ramboldia (Lecanoraceae, Ascomycota) based on morphological and molecular evidence. Nova Hedwigia 86: 23-42.

Knowles, L. \& Carstens, B. 2007. Delimiting species without monophyletic gene trees. Systematic Biology 56: 887-895.

Kroken, S. \& Taylor, J.W. 2001. A gene genealogical approach to recognize phylogentic species boundaries in the lichenized fungus Letharia. Mycologia 93: 38-53.

Lohtander, K., Källersjö, M. \& Tehler, A. 1998a. Dispersal strategies in Roccellina capensis (Arthoniales). Lichenologist 30: 341-350.

Lohtander, K., Myllys, L., Sundin, R., Källersjö, M. \& Tehler, A. 1998b. The species pair concept in the lichen Dendrographa leucophaea (Arthoniales): analyses based on ITS sequences. The Bryologist 101: 404-411.

Lohtander, K., Källersjö, M., Moberg, R. \& Tehler, A. 2000. The family Physciaceae in Fennoscandia: phylogeny inferred from ITS sequences. Mycologia 92: 728-735.

Lumbsch, H.T., Schmitt, I., Barker, D. \& Pagel, M. 2006. Evolution of micromorphological and chemical characters in the lichen-forming fungal family Pertusariaceae. Biological Journal of the Linnean Society 89: 615-626.

Lumbsch, H.T., Schmitt, I., Mangold, A. \& Wedin, M. 2007. Ascus types are phylogenetically misleading in Trapeliaceae and
Agyriaceae (Ostropomycetidae, Ascomycota). Mycological Research 111: 1133-1141.

Lumbsch, H.T. \& Huhndorf, S.M. (eds.). 2007. Outline of Ascomycota-2007. Myconet 13: 1-58.

Lutzoni, F., Pagel, M. \& Reeb, V. 2001. Major fungal lineages are derived from lichen symbiotic ancestors. Nature 411: 937-940.

Maddison, W.P. \& Knowles, L.L. 2006. Inferring phylogeny despite incomplete lineage sorting, Systematic Biology 55:21-30.

Mattsson, J.E. \& Lumbsch, H.T. 1989. The use of the species pair concept in lichen taxonomy. Taxon 38: 238-241.

Mayr, E. 1942 Systematics and the Origin of Species. Columbia University Press, New York.

Mayr, E. 1999. Systematics and the Origin of Species from the Viewpoint of a Zoologist. Harvard University Press, Cambridge. $382 \mathrm{pp}$.

Molina, M.C., Crespo, A., Blanco, O., Lumbsch, H.T. \& Hawksworth, D.L. 2004. Phylogenetic relationships and species concepts in Parmelia s. str. (Parmeliaceae) inferred from nuclear ITS rDNA and ?-tubulin sequences. Lichenologist 36: 37-54.

Murtagh, G.J., Dyer, P.S., Furneaux, P.A. \& Crittenden, P.D. 2002. Molecular and physiological diversity in the bipolar lichen-forming fungus Xanthoria elegans. Mycological Research 106: $1277-1286$

Myllys, L., Lohtander, K., Källersjö, M. \& Tehler, A. 1999. Sequence insertions and ITS data provide congruent information on Roccella canariensis and R. tuberculata (Arthoniales, Euascomycetes) Phylogeny. Molecular Phylogenetics and Evolution 12: 295-309.

Myllys, L., Lohtander, K. \& Tehler, A. 2001. $\beta$-tubulin, ITS and group I intron sequences challenge the species pair concept in Physcia aipolia and P. caesia. Mycologia 93: 335-343.

Myllys, L. Stenroos, S., Thell, A. \& Ahti, T. 2003. Phylogeny of bipolar Cladonia arbuscula and Cladonia mitis (Lecanorales, Euascomycetes). Molecular Phylogenetics and Evolution 27: 58-69.

Nelsen, M.P. \& Gargas, A. 2008. Dissociation and horizontal transmission of codispersing lichen symbionts in the genus Lepraria (Lecanorales: Stereocaulaceae). New Phytologist 177: 264-275.

Nixon, K.C. 1999. The parsimony ratchet, a new method for rapid parsimony analysis. Cladistics 15: 407-414.

Otálora, M.A.G., Martínez, I., Molina, C., Aragón, G. \& Lutzoni, F. 2008. Phylogenetic relationships and taxonomy of the Leptogium lichenoides group (Collemataceae, Ascomycota) in Europe. Taxon 57: 907-921.

Pérez-Ortega, S. \& Printzen, C. 2008. Plastis morphology in lichen misleads taxonomy and biogeography. Abstracts of the IAL 6, Asilomar, California.

Petersen, R.H. \& Hughes, K.W. 1998. Mating systems in Omphalotus (Paxillaceae, Agaricales). Plant Systematics and Evolution 211: 217-229.

Pfenninger, M. \& Schwenk K. 2007. Cryptic animal species are homogeneously distributed among taxa and biogeographical regions. BMC Evolutionary Biology 7: 121 (doi: 10.1186/14712148-7-121)

Piercey-Normore, M.D. 2006. The lichen-forming ascomycete Evernia mesomorpha associates with multiple genotypes of Trebouxia jamesii. New Phytologist 169: 331-344.

Poelt, J. 1963. Flechtenflora und Eiszeit in Europa. Phyton, Ann. Rei Bot. 10: 206-215.

Poelt, J. 1970. Das Konzept der Artenpaare bei den Flechten. Vorträge aus dem Gesamtgebiet der Botanik 4: 187-198. 
Poelt, J. 1972. Die taxonomische Behandlung von Artenpaaren bei den Flechten. Botaniska Noticer 125: 77-81.

Printzen, C., Ekman, S. \& Tønsberg, T. 2003: Phylogeography of Cavernularia bultenii: evidence of slow genetic drift in a widely disjunct lichen. Molecular Ecology 12: 1473-1486.

Purvis, A., Gittleman, J.L. \& Brooks, T. (eds.). 2005. Phylogeny and Conservation. Cambridge University Press, Cambridge.

Reeb, V., Lutzoni, F. \& Roux, C. 2004. Contribution of RPB2 to multilocus phylogenetic studies of the Pezizomycotina (euascomycetes, Fungi) with special emphasis on the lichen-forming Acarosporaceae and evolution of polyspory. Molecular Phylogenetics and Evolution 32: 1036-1060.

Robinson, H. 1975. Considerations on the evolution of lichens. Phytologia 32: 407-413.

Rokas, A., G., Payne, N.D., Fedorova, S.E., Baker, M., Machida, J., Yu, D.R., Georgianna, R.A., Dean, D., Bhatnagar, T.E., Cleveland, J.R., Wortman, R., Maiti, V., Joardar, P., Amedeo, D.W., Denning \& Nierman, W.C. 2007. What can comparative genomics tell us about species concepts in the genus Aspergillus? Studies in Mycology 59: 11-17

Saez, A.G. \& Lozano, E. 2005. Body doubles. Nature 433: 111.

Schmitt, I., Mueller, G. \& Lumbsch, H.T. 2005. Ascoma morphology is homoplaseous and phylogenetically misleading in some pyrenocarpous lichens. Mycologia 97: 362-374.

Taylor, J.W., Jacobson, D.J., Kroken, S., Kasuga, T., Geiser, D.M., Hibbett, D.S. \& Fisher, M.C. 2000. Phylogenetic species recognition and species concepts in fungi. Fungal Genetics and Biology 31:21-32.

Taylor, T.N., Klavins, S.D., Krings, M., Taylor, E.L., Kerp, H. \& Hass, H. 2004.Fungi from the Rhynie chert: a view from the dark side. Transactions of the Royal Society of Edinburgh: Earth Sciences 94: 457-473

Tehler, A. 1982. The species pair concept in lichenology. Taxon 31: 708-717.
Tehler, A. \& Irestedt, M. 2007. Parallel evolution of lichen growth forms in the family Roccellaceae (Arthoniales, Ascomycota). Cladistics 23: 432-454.

Templeton, A.R. 1989. The meaning of species and speciation: A genetic perspective. In: Otte, D. \& Endler, J. (eds.), Speciation and its consequences. Sunderland, MA: Sinauer.

Thell, A., Hansen, E.S., Kärnefelt, I. \& Feuerer, T. 2007. The distribution of Parmelia ernstiae in Denmark. Bibliotheca Lichenologica 96: 299-304.

Thell, A., Elix J.A., Feuerer, T., Hansen, E.S., Kärnefelt, E.I., Schüler, N. \& Westberg, M. 2008. Notes on the systematics, chemistry and distribution of European Parmelia and Punctelia species (lichenized ascomycetes). Sauteria 15: 545-559.

Wedin, M. 1993. A phylogenetic analysis of the lichen family Sphaerophoraceae (Caliciales); a new generic classification and notes on character evolution. Plant Systematics and Evolution 187: 213-241.

Wiens, J.J. \& Penkrot, T.L. 2002. Delimiting species based on DNA and morphological variation and discordant species limits in spiny lizards (Sceloporus). Systematic Biology 51: 69-91.

Wirtz, N., Printzen, C. \& Lumbsch, H.T. 2008. The delimitation of Antarctic and bipolar species of neuropogonoid Usnea (Ascomycota, Lecanorales): a cohesion approach of species recognition for the Usnea perpusilla complex. Mycological Research 112: 472-484.

Yahr, R., Vilgalys, R. \& DePriest, P.T. 2006. Geographic variation in algal partners of Cladonia subtenuis (Cladoniaceae) highlights the dynamic nature of a lichen symbiosis. New Phytologist 172: $847-860$.

Received: 18-XII-2008 Accepted: 3-III-2009 